\title{
Understanding the Water Balance of Potentially Acid Forming Tailings Deposited in a Dry Climate
}

\author{
P.J. Chapman Golder Associates Pty Ltd, Australia \\ D.J. Williams The University of Queensland, Australia
}

T.K. Rohde The University of Queensland, Australia

S.J. Ennor Xstrata Nickel Australasia, Cosmos Nickel Project, Australia

\begin{abstract}
The conventional deposition of mine tailings as a slurry results in seepage, with the potential to contaminate surface and ground waters, particularly during deposition, and possibly post-closure. In a dry climate, tailings deposition can be cycled to largely evaporate excess water, and on closure the tailings may remain desiccated to the extent that incidental rainfall will not cause seepage to the environment. The purpose of any cover would then be to limit dust, promote some vegetation and improve aesthetics, rather than to shed rainfall runoff, which would result in a poor vegetative cover and erosion. To test this hypothesis, a trial tailings cell at a mine in arid Western Australia has been instrumented with moisture and suction sensors located on towers placed prior to tailings deposition. Tailings were deposited over a number of months in a series of lifts to a maximum height of about $4 \mathrm{~m}$, with desiccation allowed between lifts. The deposit was then left for a period of four months without tailings deposition, during which time the effects of prevailing climatic conditions were monitored. The paper describes the instrumentation and its installation, and the life cycle of tailings deposition and desiccation, and presents the moisture and suction data collected during the deposition and desiccation phases.
\end{abstract}

\section{Introduction}

Australian mineral production was valued at over $\$ 100$ billion in $2006 / 7$, with approximately $90 \%$ of this derived from exports, representing over one third of total export earnings (ABARE, 2007). A key by-product of mineral processing is tailings, which are usually stored in surface facilities covering large areas and requiring deposition schemes and rehabilitation on closure to render them safe, stable and noncontaminating. The normal cost of managing and rehabilitating tailings may be a few percent of operating costs, but this can rise over five-fold if excessive seepage needs to be collected and treated, as has been the experience at sites such as Equity Silver in British Columbia, Canada (Wilson et al., 1997). The research was aimed at developing the most cost-effective, safe, stable and non-contaminating tailings deposition scheme and rehabilitation on closure in a dry climatic setting.

The conventional deposition of mine tailings as a slurry results in seepage, with the potential to contaminate groundwater and surface waters when the seepage transports contaminants from the tailings or tailings water. It was postulated that, in a dry climate, tailings deposition can be cycled to largely evaporate excess water, and that on closure the tailings will remain desiccated to the extent that incident rainfall will not cause seepage to the environment. In this case, the purpose of any cover would then be to limit dust and promote some vegetation, rather than to shed rainfall runoff, which would result in unsustainable vegetation and erosion. The expected outcomes of the research are greatly improved tailings deposition and rehabilitation design, implementation, economics and performance in a dry climate.

\section{Research project summary}

A key issue identified at the Cosmos Nickel Project (Cosmos), located approximately $40 \mathrm{~km}$ north of Leinster in Western Australia, is the need for the management of the tailings storage facility (TSF) and the associated environmental risk, with emphasis on seepage and groundwater monitoring, and saline water management. 
Cosmos is located in an arid climate, with an average annual rainfall of approximately $270 \mathrm{~mm}$ and an average annual pan evaporation in excess of $2500 \mathrm{~mm}$. On average, the rainfall is distributed throughout the year, with summer rains dominant and marked by occasional intense storms. Mean maximum monthly temperatures range from $19^{\circ} \mathrm{C}$ to $37^{\circ} \mathrm{C}$, and mean minimum monthly temperatures range from 6 to $23^{\circ} \mathrm{C}$. Maximum wind gusts of up to $140 \mathrm{kph}$ have been recorded, and wind gusts are common throughout the year (BoM, 2008).

At Cosmos, the foundation beneath the tailings storage facility comprises a caprock of variable thickness, with occasional breaks that would allow the percolation of any seepage. Groundwater is located at depths ranging from 3 to $23 \mathrm{~m}$ and is discontinuous, being found mainly in rock fractures. The groundwater is typically hypersaline (TDS in the range 5000 to $10,400 \mathrm{mg} / \mathrm{l}$ ), although near-surface sources of fresh water do exist, such as at the nearby Sinclair Nickel Mine, also owned by Xstrata. The processing plant sources its raw water requirement from the relatively fresh Yakabindi borefield.

A visit to the Cosmos TSF in September 2006 revealed a number of particular concerns. There is potential for saline and acidic seepage through the walls of the TSF when tailings deposition away from the wall is not properly controlled, and there is potential for the mounding, salinization and acidification of potentially usable groundwater due to seepage into the foundation beneath the TSF. This presents a requirement to address the need for, and role of, covers over closed TSFs, and to develop the optimal cover strategy to address long-term seepage, dust, vegetation and aesthetics.

Addressing the above issues and concerns, the overall objectives of the research project are to demonstrate that:

- In a dry climate, tailings deposition can be cycled to largely evaporate excess water.

- On closure of a TSF in a dry climate, the tailings will remain desiccated to the extent that incident rainfall will not cause seepage to the environment, either through the containment wall or into the foundation beneath the TSF.

- The purposes of any cover would then be to limit dust, promote some vegetation and improve aesthetics, rather than to shed rainfall runoff, thus resulting in unsustainable vegetation and erosion in a dry climate.

- Such a cover would require far less earthworks than a rainfall-shedding cover, making it far more cost-effective to construct and requiring far less maintenance due to the reduced runoff and erosion potential.

- By this combination of means, seepage from TSFs in a dry climate will be minimized, both during operation and post-closure.

- This will result in the most cost-effective operation, closure, rehabilitation and timely lease surrender of TSFs in a dry climate.

The objectives outlined above will be met by:

- Using field instrumentation to determine:

- The water balance cycle of tailings during deposition, desiccation, flooding and rehabilitation.

- The saturated and unsaturated states of the tailings.

- The net flux (whether downward seepage or upward evaporation) as a function of operating and closure conditions.

- Developing a model to represent the fluxes.

- Developing a conceptual cover design to meet the research project objectives.

The Cosmos tailings are relatively coarse-grained, silty and sand-sized, and are deposited as an aqueous slurry at an initial $40 \%$ solids by mass. The Cosmos tailings are derived from a sulphide orebody and are therefore rich in sulphides. Processing of the ore involves crushing, grinding, froth flotation and dewatering, 
requiring the addition of xanthate (collecting) and $\mathrm{pH}$ elevating chemicals to aid nickel recovery, which are retained in small concentrations in the tailings and cause its initial $\mathrm{pH}$ to be approximately 9 . On desiccation and exposure of the tailings to air, the tailings oxidize, the $\mathrm{pH}$ drops towards 4 and some metals go into solution, resulting in any seepage being acidic and metal-laden.

In the research project, particular attention is being devoted to the flow behavior of the upper, desiccated tailings, and the role these layers can play in the overall cover design.

\section{Trial cell instrumentation}

A trial cell was constructed during expansion of the Cosmos TSF to facilitate the research project. Figure 1 presents the general arrangement plan for the Cosmos TSF.

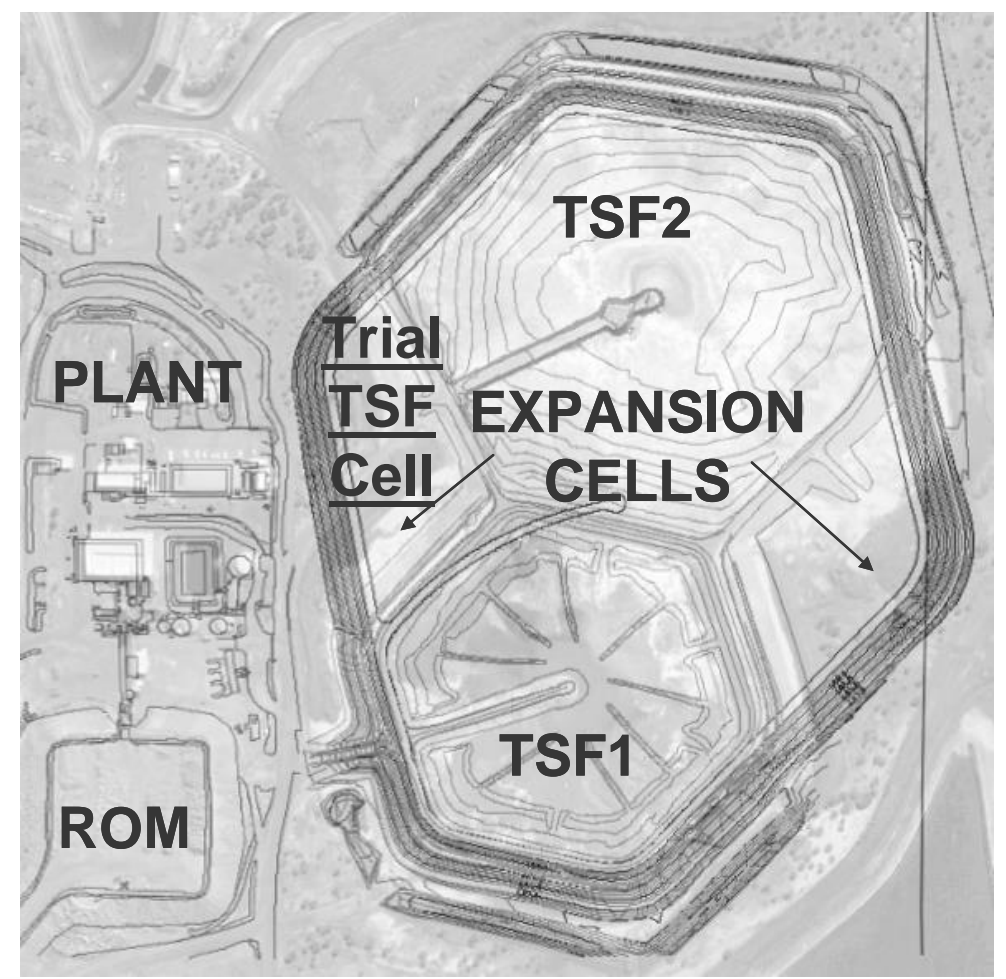

\section{Figure 1 General arrangement plan for Cosmos TSF}

The instrumentation system was mounted on two towers and comprises the following items:

- Two 5 meter high 50 millimeter square steel tube towers, with welded brackets on which to mount the sensors.

- A full Campbell Scientific weather station, measuring rainfall, temperature, wind speed, wind direction, relative humidity and solar radiation.

- Thirty-two Campbell Scientific TDR100 volumetric water content sensors (= volume of water/total volume, expressed as a decimal) and 32 Campbell Scientific 229 Heat Dissipation Matric Water Potential Sensors (16 on each tower), one located beneath the TSF base (to monitor wetting up of the foundation) and the remainder mounted on brackets at $300 \mathrm{~mm}$ intervals, up to approximately $4.2 \mathrm{~m}$ above the base (to monitor the tailings to be placed in layers as a slurry).

- Associated Campbell Scientific data loggers located on the TSF perimeter embankment to facilitate data capture and retrieval.

Figure 2 illustrates the location of the instrumentation towers and the weather station, relative to the perimeter embankment and mine site offices. Photographs of the sensors after placement on the towers are also shown. 

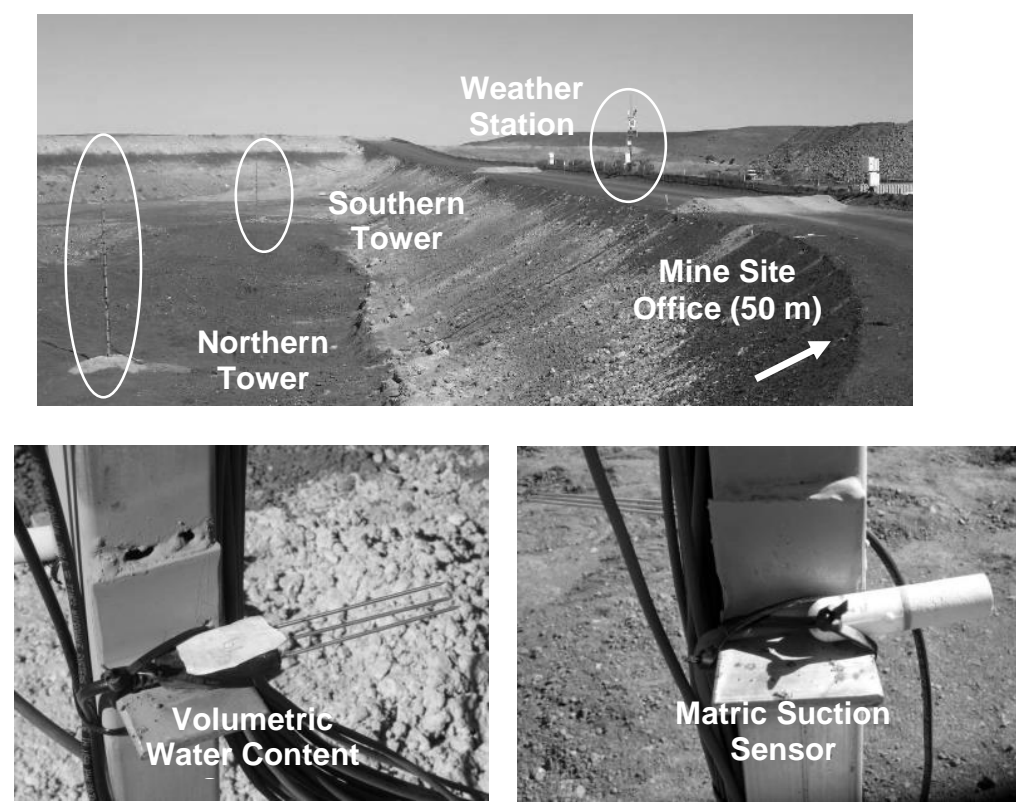

Figure 2 Locations of the instrumentation towers and weather station

Tailings deposition into the trial cell commenced in May 2007. The first site visit after the commencement of deposition was carried out on 16 May 2007. Figure 3 illustrates the trial tailings cell shortly after the commencement of deposition.

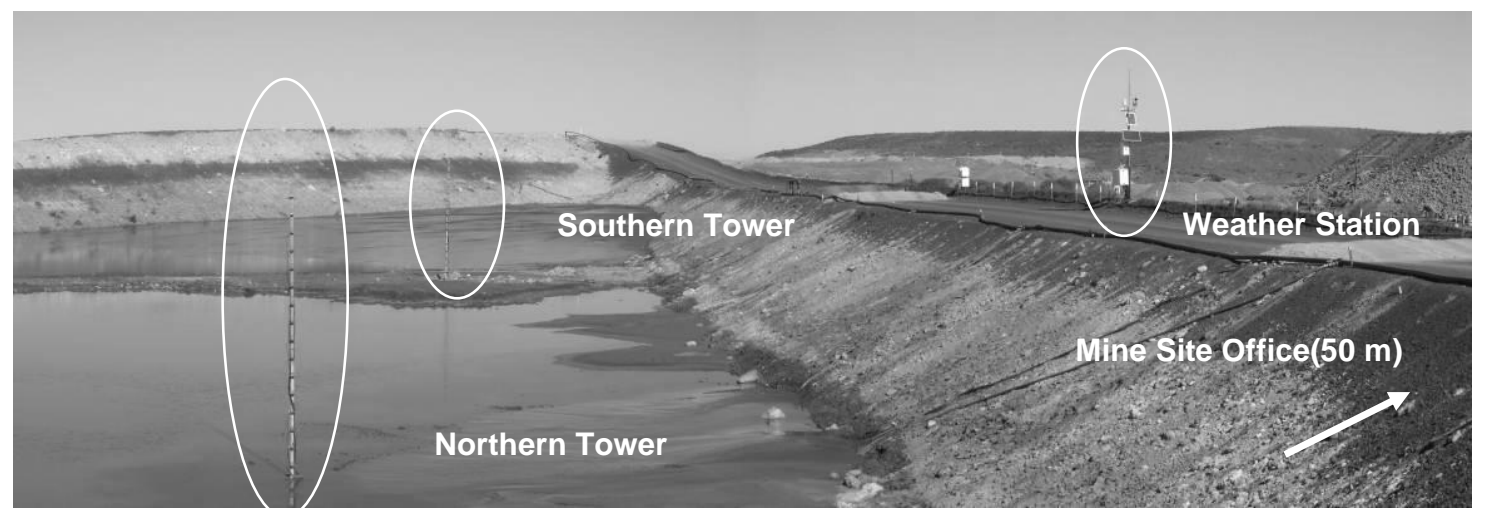

Figure 3 Commencement of tailings deposition into the trial cell

Further deposition occurred during 2007, with progressive development of a tailings beach, through successive deposition and desiccation periods (Figure 4). 


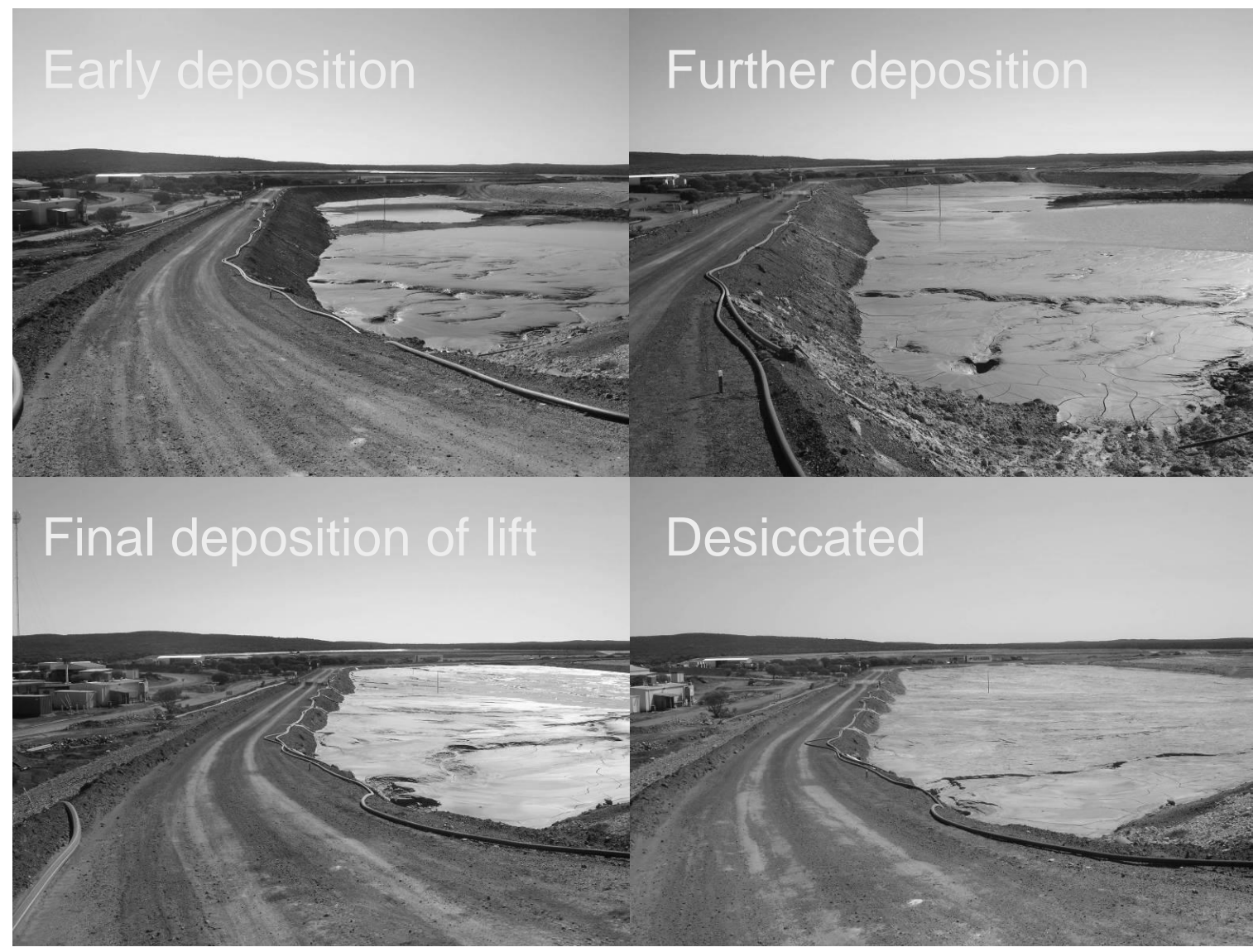

Figure 4 Further deposition and desiccation of tailings in the trial cell

\section{$4 \quad$ Field monitoring data and discussion of results}

Data logging commenced on 22 May 2007, shortly after the commencement of tailings deposition. The data collected are presented below, along with discussion of aspects of the collected data that are relevant to the deposition and subsequent desiccation cycles, and TSF closure design. Data presented in this paper are limited to the period between 22 May and 31 December 2007.

\subsection{Tailings deposition}

Tailings deposition was monitored through visual observations of the tailings beach in relation to sensors located on each tower. Daily observations were recorded by Cosmos personnel during two periods of deposition: 17 May to 19 July (64 days), and 26 October to 16 November ( 22 days), with a fallow period of 97 days in between cycles. The elevation of the tailings beach at each instrumentation tower is presented in Figure 5.

Figure 5 illustrates the relatively high rates of rise associated with deposition into the trial cell. Typically, rates of rise for sub-aerial deposition of hard rock nickel tailings in arid environments are limited to approximately $2 \mathrm{~m} / \mathrm{year}$. The annualized average rate of rise for the initial seven months of operation of the trial cell was approximately $4 \mathrm{~m} / \mathrm{year}$. The higher than normal rate of rise was due to the need to match production rates, and is expected to result in lower consolidation of the tailings, less evaporation from the tailings beach and potentially higher seepage rates, than would normally occur. The results from the instrumentation are therefore considered to be conservative, as a lower rate of rise would increase the effective desiccation, and reduce seepage from the TSF. 


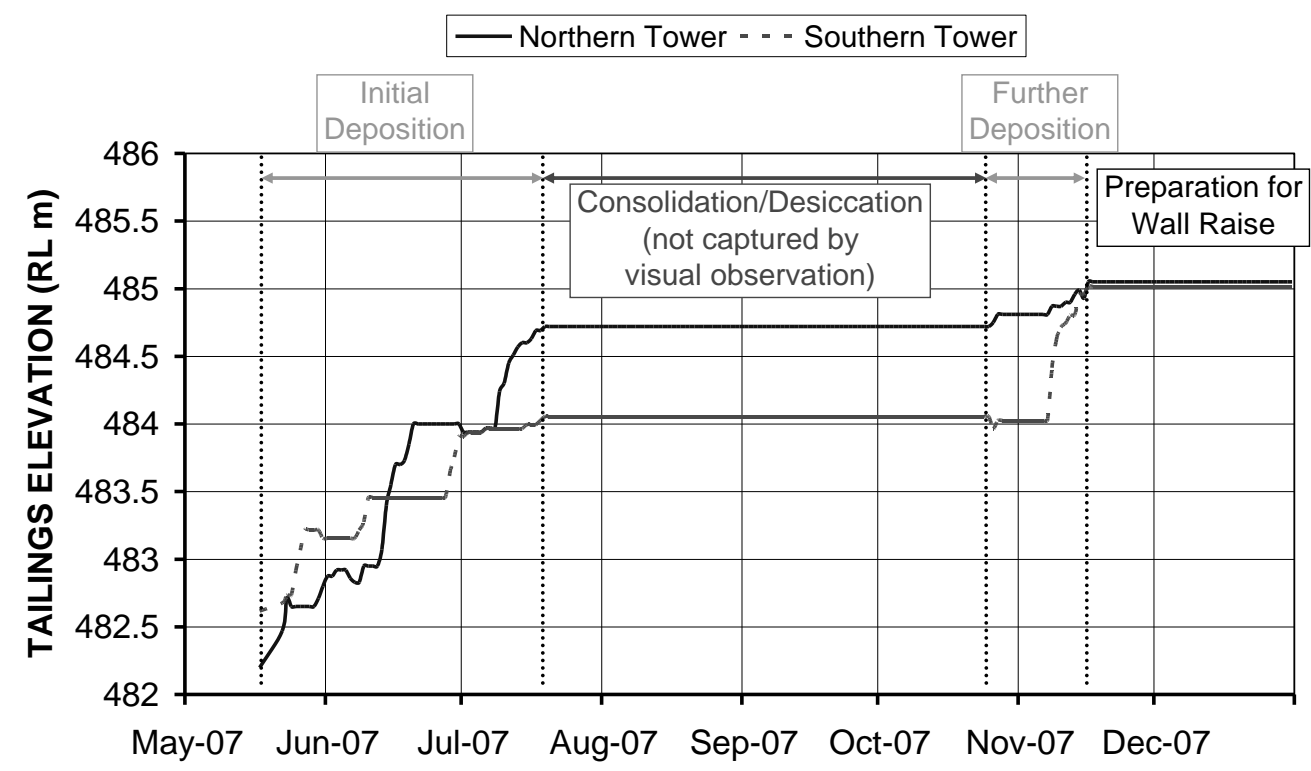

Figure 5 Increase in tailings elevation during deposition

\subsection{Weather station data}

The on-site weather station was configured to record daily values, averaged from thirty minute periodic readings. Hourly data were also collected. Staff at the Cosmos mine site recorded the air temperature and rainfall for their own records. The daily and cumulative rainfalls are presented in Figure 6.

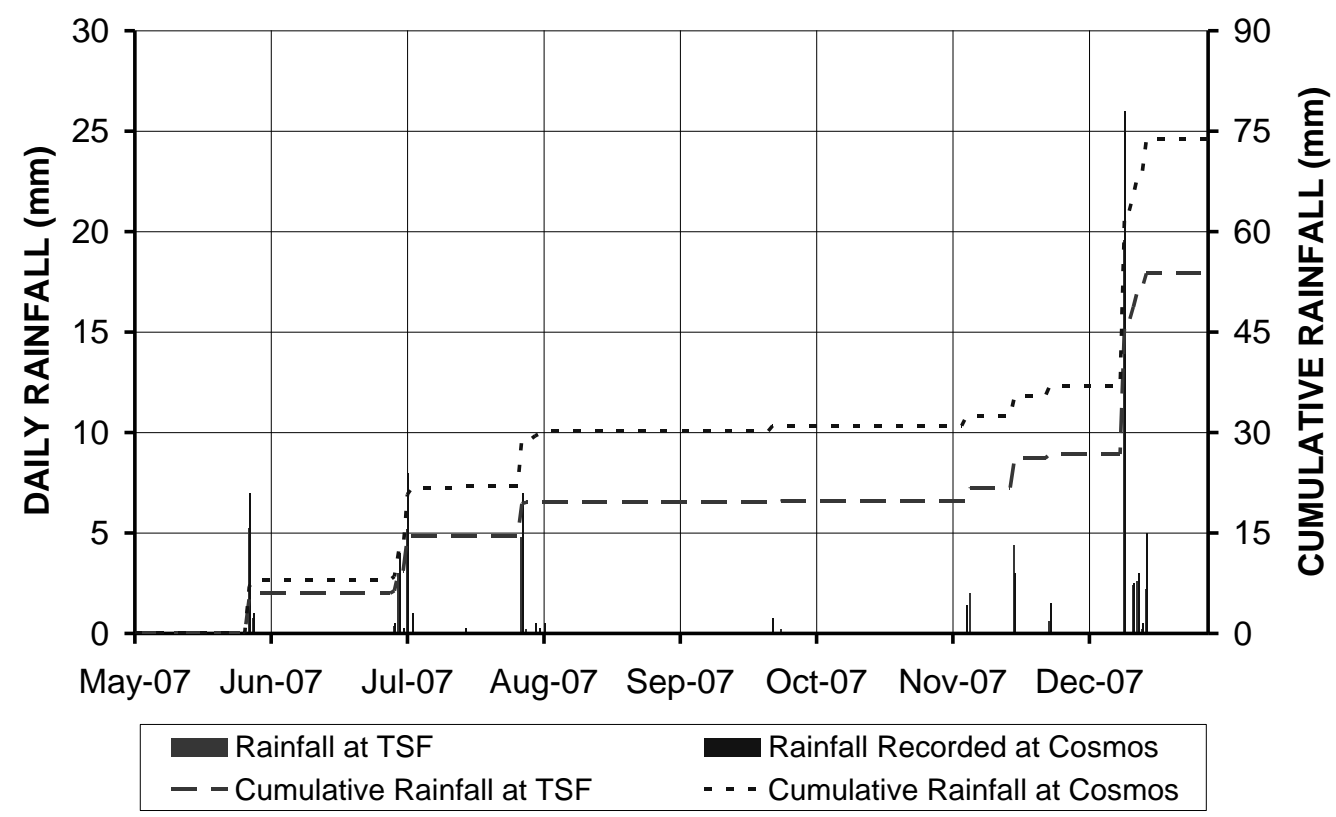

Figure 6 Daily rainfall recorded at TSF and at Cosmos weather station

The rainfall values show some variation between the automated trial cell and manual readings, probably as a result of the difference in elevation (the wall of the trial cell is about $5 \mathrm{~m}$ higher) and the difference in location (about 1 kilometer) of the collection points. However, the results indicate that there was minimal rainfall during the period of data collection. Anecdotal evidence and analysis of rainfall records indicates that the majority of rainfall occurs during the summer months, as a result of tropical storms migrating south from the north-west coast of Western Australia. It is therefore expected that the majority of the rainfall will occur 
between January and March. The impact of the total annual rainfall will be incorporated into later stages of the research project.

\subsection{Conceptual annual water balance}

A conceptual annual water balance estimate for the Cosmos TSF, based on data from previous annual reports, is summarized in Table 1 .

Table 1 Cosmos TSF conceptual annual water balance

\begin{tabular}{ll}
\hline Water Additions to TSF & Water Removals from TSF \\
\hline Slurry water (measured): 92\% & Return water (measured): $37 \%$ \\
Rainfall (measured): $8 \%$ & Evaporation (estimation): $34 \%$ \\
& Pore water (estimated from in situ \\
& samples): $15 \%$ \\
& Seepage (net difference): $14 \%$ \\
\hline
\end{tabular}

The water balance indicates that the typical ratio of slurry water to rainfall is in excess of ten to one on an annual basis. The water balance also indicates that seepage from the TSF is only about $14 \%$ of the total water addition to the TSF.

Analysis of the cumulative tailings water and rainfall for the period of data collection is presented in Figure 7.

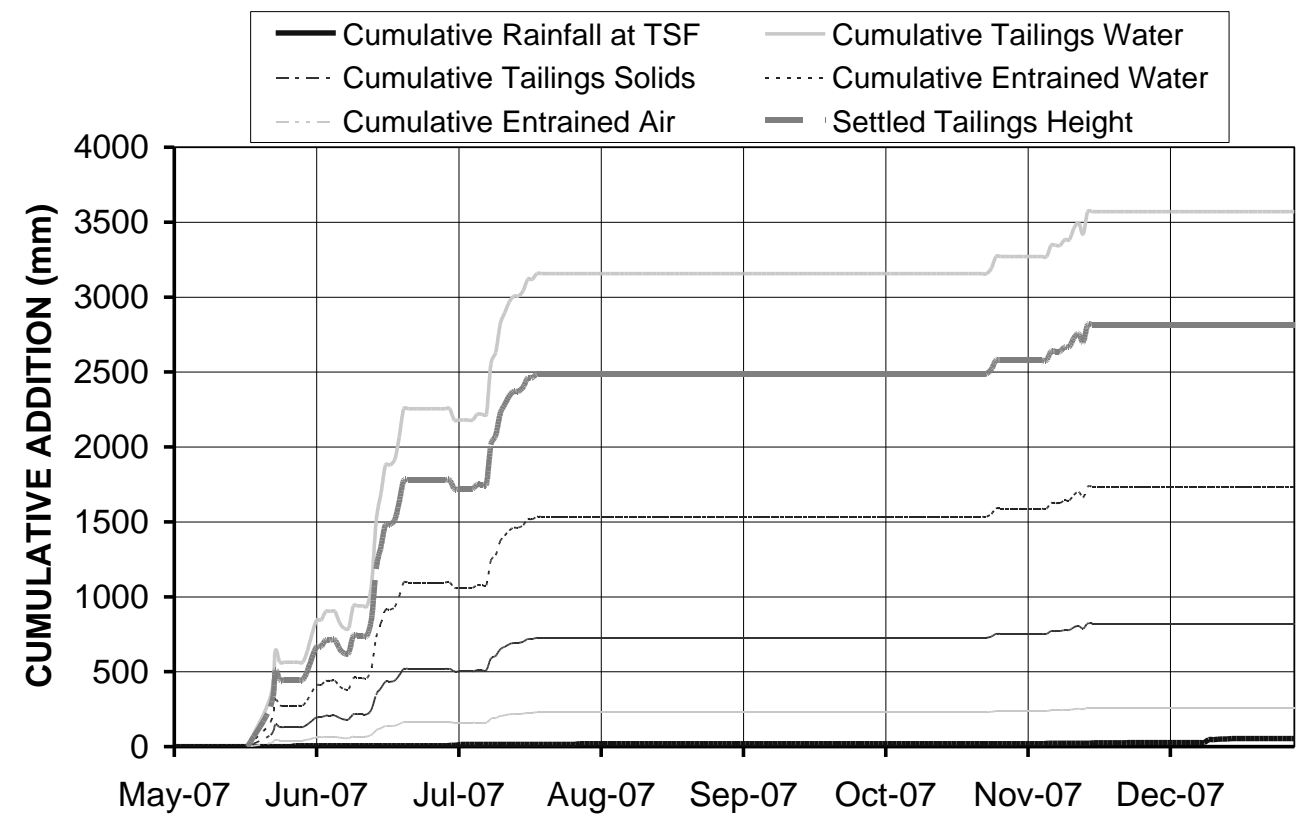

Figure 7 Analysis of water and slurry additions to TSF during deposition

The data collected for the period ending 31 December 2007 indicates that the ratio of slurry water addition to rainfall addition is in the order of 80 to 1 , significantly higher than the 10 to 1 ratio indicated by the annual water balance. However, as outlined above, the majority of rainfall occurs during January to March, which is likely to reduce the estimated ratio to a number similar to the annual figure.

\subsection{Monitoring data}

\subsubsection{Moisture data}

The volumetric water content versus time data collected at the Northern Tower are presented in Figure 8. 
Moisture Data Collected from Northern Tower Deposition from 17 May to 19 July \& 26 Oct to 16 Nov 2007

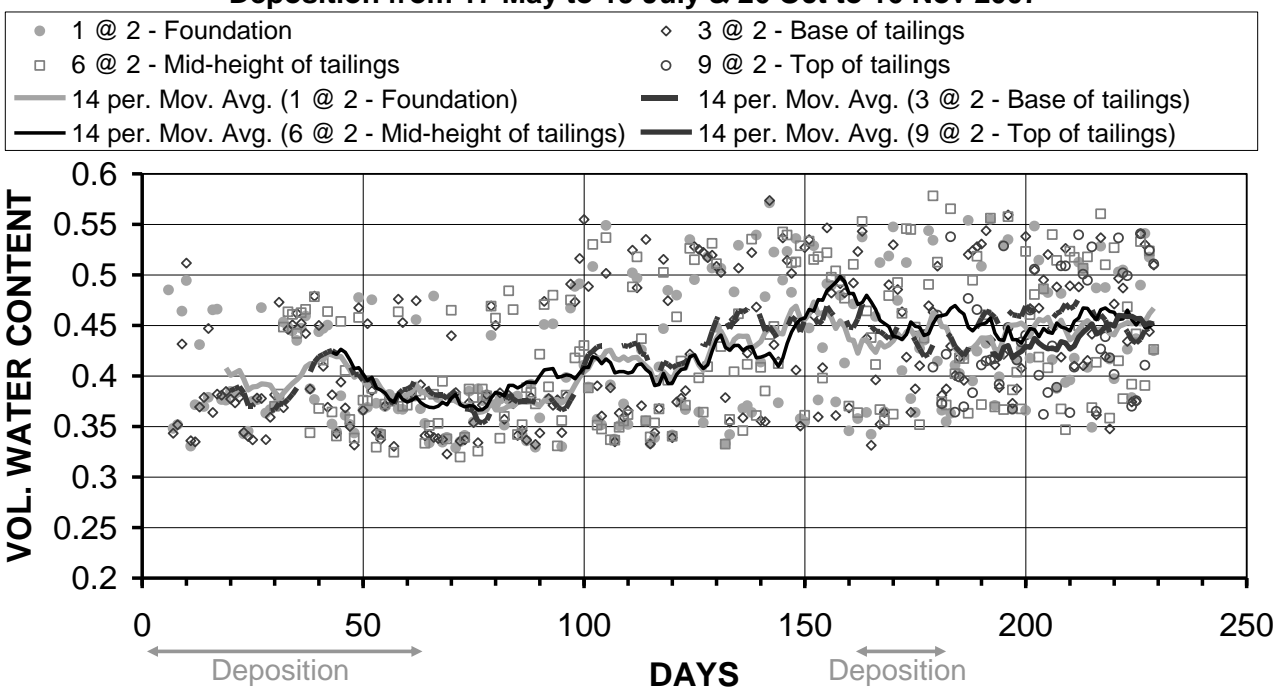

\section{Figure 8 Moisture data for Northern Tower}

Figure 8 suggests that the volumetric water content of the tailings varies from 0.57 for fresh tailings to 0.32 for desiccated tailings, with an average of about 0.40 . The average volumetric water content is dominated by desiccation, although the overall trend suggests that it is increasing over time. This is thought to be a result of the increasing cumulative volume of tailings water over time.

When the volumetric water content is plotted against sensor depth, as in Figure 9, it is evident that there is no obvious trend with elevation. The process of deposition and desiccation, and the ability of the tailings to lose and gain water, is clear from the range of values. The data also suggests that sensors near the foundation are recharging to some extent, indicating that there are hydraulic connections through the tailings, probably as a result of the high rate of rise and lack of time for desiccation to occur between deposition cycles. The particle size distribution of the tailings at a given elevation will also vary considerably due to hydraulic sorting on deposition, accounting for much of the variation of volumetric water content.

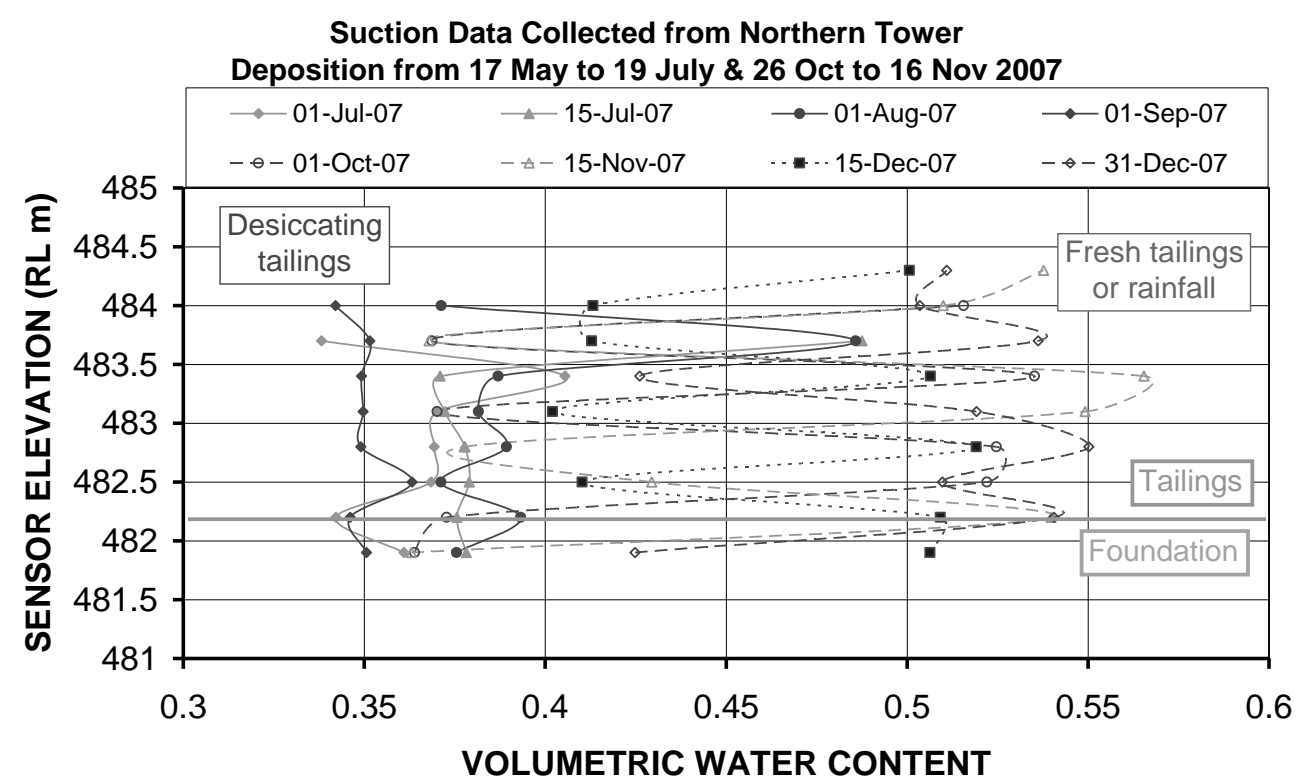

Figure 9 Moisture data with respect to sensor elevation 


\subsubsection{Suction data}

Suction data were collected at the Northern and Southern Towers on a daily basis. Figure 10 presents the data collected from the Northern Tower for the suction range from 0 to $10 \mathrm{kPa}$. Suctions in the order of $100 \mathrm{kPa}$ were achieved in the near-surface tailings on desiccation.

Suction Data Collected from Northern Tower Deposition from 17 May to 19 July \& 26 Oct to 16 Nov 2007

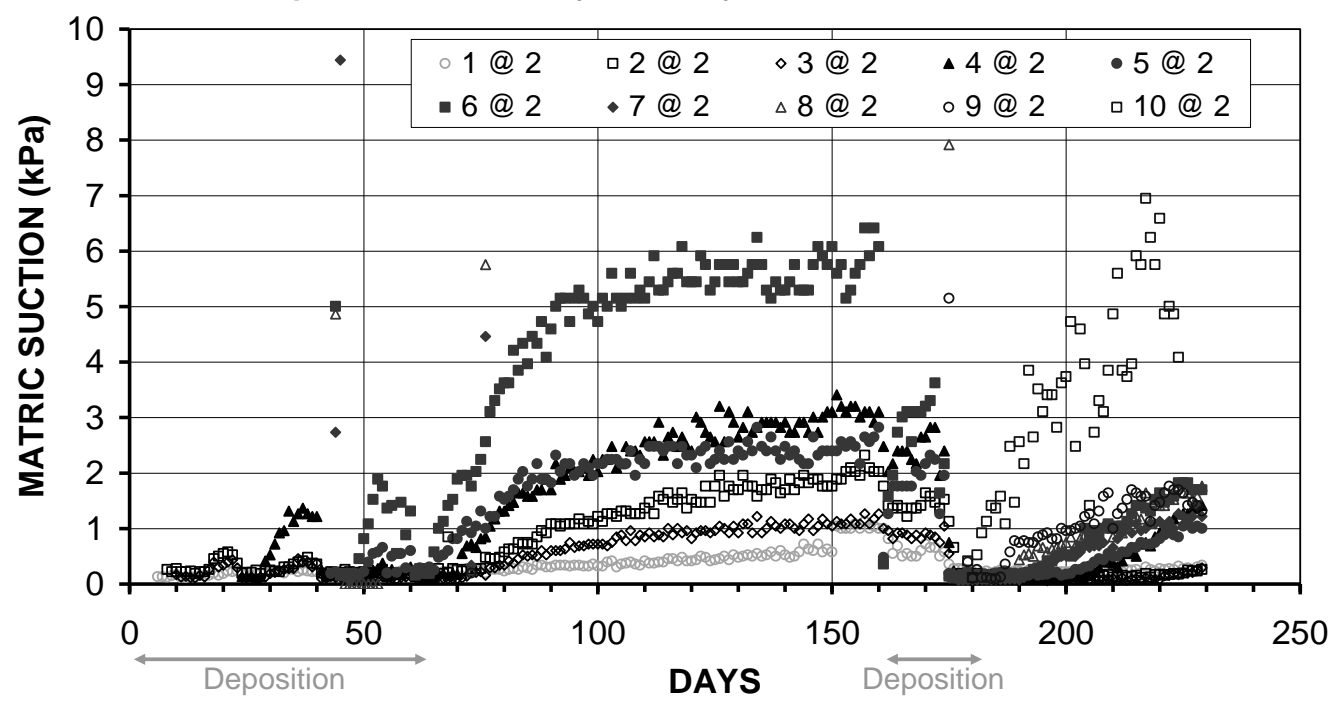

Figure 10 Suction data for Northern Tower

Figure 10 highlights the two periods of desiccation immediately following the cessation of deposition. The data indicate that while most of the desiccation occurs towards the surface of the tailings, some desiccation is evident for the lower sensors, and even in the foundation (Sensor 1, at a depth of almost $3 \mathrm{~m}$ ). Once deposition recommences, the suction values indicate that the tailings and foundation resaturate, suggesting that a hydraulic connection through the tailings column occurs. This is consistent with the moisture content data presented above.

Figure 11 illustrates a number of deposition and desiccation cycles observed during the data period analyzed. The data clearly show desiccation from the surface, but extending throughout the tailings column. It is postulated that if the tailings were allowed to desiccate for a sufficient period of time, the suctions observed in the foundation levels may increase to a point at which the reduced unsaturated hydraulic conductivity inhibits future infiltration. It is further postulated that, for a given tailings depth, there is a suction level that would reduce the hydraulic conductivity to sufficiently low values that would prevent the reformation of a hydraulic connection, resulting in a cessation of seepage from the tailings. 


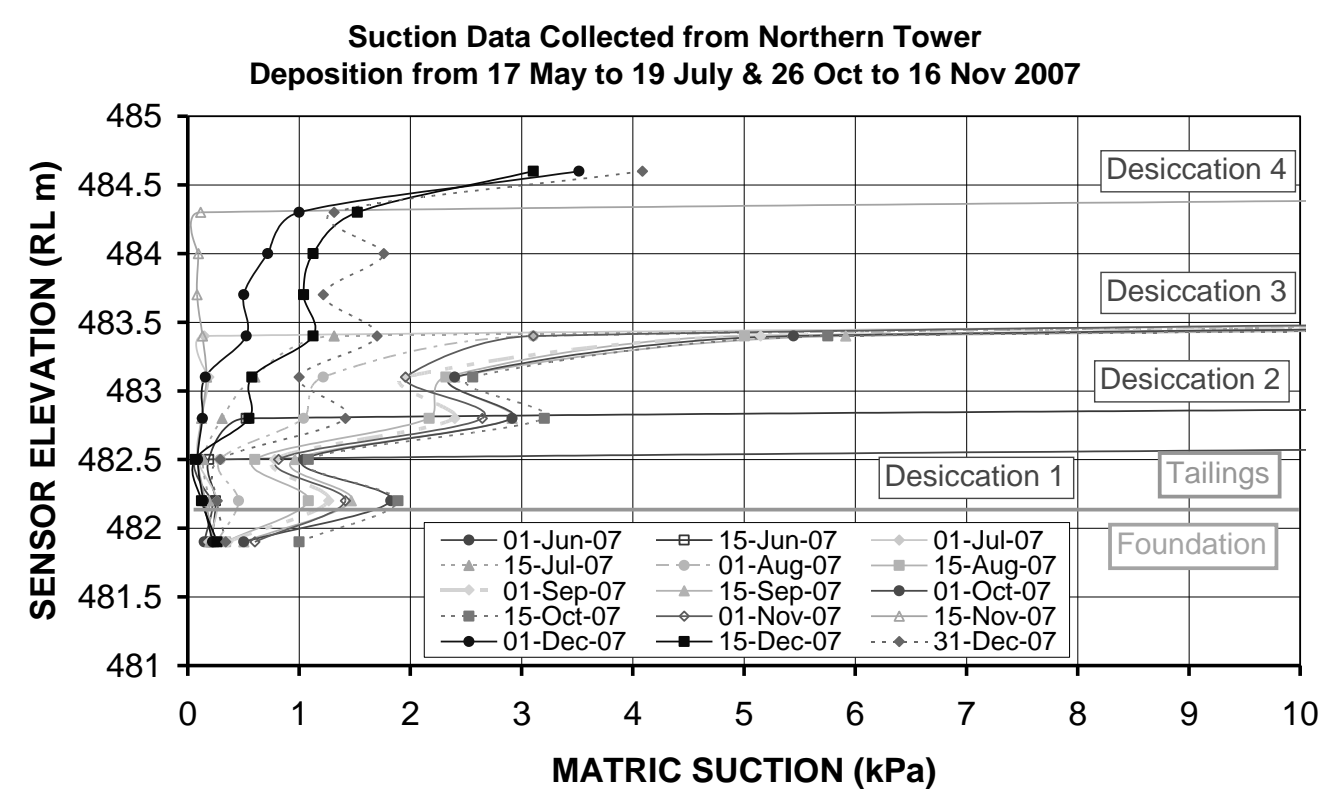

Figure 11 Suction data with respect to sensor elevation

To test these theories with the data collected in 2007, the depth of penetration of storm events was analyzed. Figure 12 illustrates the effect of two minor and one major storm events on the suction values measured within the tailings column.

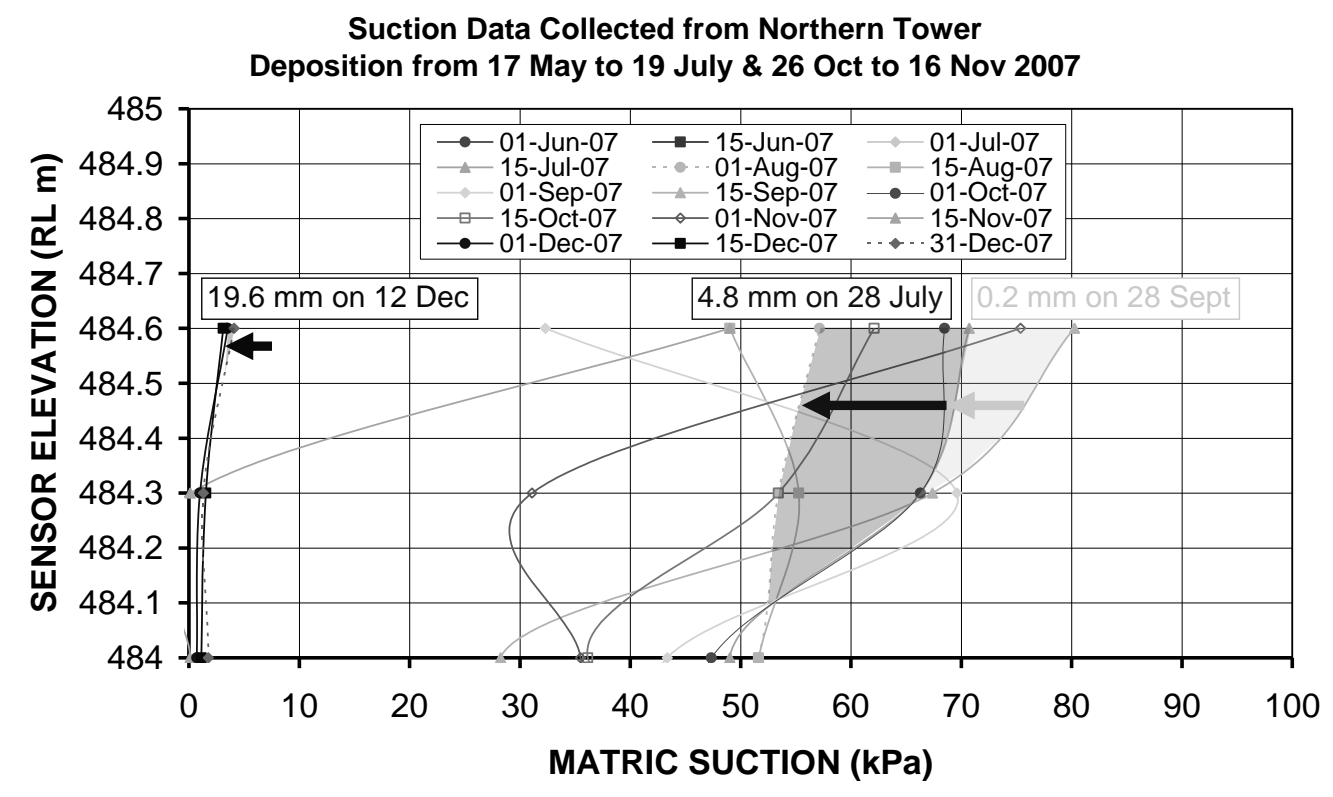

Figure 12 Effect of rainfall on suction in the tailings column 
The two minor storms (28 July and 28 September) resulted in a minor decrease in suction as a result of the wetting front infiltrating into the tailings column, to depths of $0.5 \mathrm{~m}$ and $0.3 \mathrm{~m}$, respectively. On 12 December, a rainfall of $19.6 \mathrm{~mm}$ was recorded at the weather station adjacent to the trial tailings cell. However, as deposition had only recently ceased, desiccation of the tailings had not yet occurred and the saturated tailings did not wet up but simply passed water at their saturated hydraulic conductivity.

\section{Conclusions and further work}

A trial TSF cell has been constructed at Cosmos Nickel Mine in Western Australia, instrumented prior to tailings deposition with volumetric water content and matric suction sensors, and progressively filled with tailings from 17 May 2007. The monitoring data collected to 31 December 2007 suggest that:

- Rapid desiccation occurs following the cessation of tailings deposition, including of the foundation.

- Rapid wetting-up of the desiccated tailings occurs during deposition of fresh tailings or rainfall.

- The majority of the considerable surplus water evaporates.

Assuming that the tailings are allowed to desiccate for a sufficiently long time period, the likelihood of rainfall events infiltrating the tailings and reforming a hydraulic connection with the groundwater table will be low, thus resulting in negligible long-term seepage.

To demonstrate that the upper, desiccated tailings layers can form part of an integrated cover zone, the following will be carried out:

- Continue to monitor the trial TSF cell, monitor/simulate large rainfall events and monitor the resulting seepage flux.

- Conduct laboratory testing and construct an instrumented, large-scale laboratory column to test the Cosmos tailings.

- Using existing software, develop a numerical model to simulate the field and laboratory results.

- Develop a cover design to meet the project objectives and subsequently construct instrumented trial covers.

\section{Acknowledgements}

The authors of this paper would like to acknowledge the support of Golder Associates (Perth Office), The University of Queensland and Cosmos site personnel for their assistance with construction and installation of the instrumentation towers, and ongoing data collection.

\section{References}

Australian Bureau of Agricultural and Resource Economics (ABARE), viewed 20 June 2008, $<$ http://www.abare.gov.au>

Bureau of Meteorology (BoM), viewed 20 June 2008, 〈http://www.bom.gov.au>

Wilson, G.W., Newman, L.L., Barbour, S.L., O'Kane, M.A., and Swanson, D.A. (1997) Show Case Paper, The Cover Research Program at Equity Silver Mine Ltd, Proceedings of the Fourth International Conference on Acid Rock Drainage, Vancouver, Canada - June 6, Vol. I, pp. 197-210. 
